\title{
What Do the University Students Think about Erasmus Programme in Turkey?
}

\author{
Verda Gizem Ogul \\ Marmara University, School of Foreign Languages, Goztepe Campus 34722 Kadikoy, Istanbul, Turkey
}

How to cite this paper: Ogul, V. G. (2018). What Do the University Students Think about Erasmus Programme in Turkey? The Educational Review, USA, 2(5), 296-308. http://dx.doi.org/10.26855/er.2018.05.004

Corresponding author: Verda Gizem Ogul, Ph.D., Marmara University, School of Foreign Languages, Goztepe Campus 34722 Kadikoy, Istanbul, Turkey.

\begin{abstract}
Student mobility has been one of the most important subjects of higher education students in Europe since the beginning of 1980's. Furthermore, Socrates/Erasmus program has been the most successful component of European Union (EU) policy. We have focused on the Erasmus program because it represents the most popular scheme of student mobility at the European level. This article analyses the Erasmus program from the point of view of Turkish university students. For this purpose, 15 itemed questionnaires were prepared. We grouped the questions into 4 sub-categories; information about and expectations from the EU, contribution of the Erasmus Programme (EP) to students' self-development, contribution of the EP to the institution's development and global benefits and expectations of the EPstudent knowledge about European Union, student dimension of Erasmus programme, institutional dimension and global profits of Erasmus Programme. This questionnaire was administered to 1546 university students to describe the results about Erasmus Programme in Turkey. The problem statements are; what the university students think about membership of Turkey to EU. Do they think they have knowledge of Erasmus Programme, individual benefits of Erasmus programme and also institutional benefits of Erasmus programme? In this research five-level Likert type scale is used.
\end{abstract}

\section{Keywords}

Erasmus Programme, Erasmus Student Mobility, Higher Education, Bologna Process, European Union

\section{Introduction}

The Erasmus Programme has been an EU student mobility program at the European level since the late 1980s. Since the beginning of Erasmus Programme (1987) close to 3 million students have participated this programme. Besides, since 1997 over 300,000 higher education teachers and staff have been attended the same programme. In 2012 Erasmus programme celebrated its 25th anniversary. Each year more than 230,000 students study abroad, the average period of stay six months. The annual budget is in excess of 450 million euro; more than 4,000 higher education institutions in 33 countries participate, and many more higher education institutes are willing to join this programme (European Commission, 2013). This Programme is the most popular scheme of student mobility at the European level. According to Teicher (2001) it could be considered as the flagship of all educational programmes at the EU level. In addition, starting from Socrates and then Erasmus programmes have been the most successful component of EU policy (Altbach and Teicher, 2001). Erasmus exchange students could pursue their modules in more than one European County with the help of common framework of credits which is called The European Credit Transfer System (ECTS). For an Erasmus exchange 
student the normal workload for a semester is 30 ECTS credits. In most of the countries, a 10-credit module equates to five ECTS (Mercer, 2011).

European fellowship programs are provided by the Erasmus Programme to cover the additional costs for studying in another country of the European Commission (EC) for a period between three months and one year. Inter-university Cooperation Programmes (ICPs) facilitate student exchange academically and also administratively. ICPs also support the general expenses, language courses, staff travel. In addition, the partner universities have to accept that students do not pay tuition fees at the host university (Teicher, 1996).

\section{Bologna Process and Erasmus Programme}

When the European ministers of education met to celebrate the 600th anniversary of the University of Bologna, the Bologna Declaration was issued in 1999. The main goal of the Declaration was the establishment of a European Higher Education Area by the year of 2010. This Process aims the harmonization of the different higher education systems in the region. In a manner of European Law harmonization means the approximation of national laws in order to create one European standard (Garben, 2010; Kehm, 2010). The Bologna Process is an intergovernmental policy agenda which is currently signed by forty-six national governments including all twenty-seven of the EU countries and nineteen non-EU countries. This declaration aims to set a series of measures towards harmonizing educational standards in the different countries of Europe. Another purpose of Bologna Process is to promote mobility and recognition of professional qualifications across national borders. In addition, it increases the international competitiveness and to ensure a world-wide degree of the European system (Engelberg and Limbach-Reich, 2012; Brookes and Huisman, 2009).

The higher education sector in Europe has undergone reform processes based on several European conventions and communiqués: Sorbonne (1998), Bologna (1999), Prague (2001), Berlin (2003), Bergen (2005), London (2007) and Louven (2010). For comparing, describing and understanding differences between degree programs of Bologna Process in different countries, there is an increasing interest in developing systems of procedures and methods of applications (Sihvonen et al, 2011). The Bologna Process members were targeted to creating the European Higher Education Area (EHEA) between the years 1999-2010, all the efforts of the Bologna Process members were targeted to creating the European Higher Education Area (EHEA), which became reality with the Budapest-Vienna Declaration of March, 2010 (European Commission, 2007). The building of EHEA makes European Higher Education system more comparable, compatible and coherent. Increasing student mobility remains an important political goal in the context of the Bologna Process. To provide the richness of the European Higher Education Area mobility of students, teachers, researchers and administrative staff must be continued. It helps the diversification of cultures and languages and also higher education systems (Papatsiba, 2005). To create EHEA, an easily readable and comparable degree of the system should be established. At first two ties system were developed and after that a three ties system and ECTS $(3+2+3)$ has been started to use by Higher Education Institutes (Furuzan, 2012). In this system;

- $\quad$ First cycle: typically 180-240 ECTS credits, usually awarding a bachelor's degree.

- Second cycle: typically 90-120 ECTS credits (a minimum of 60 on 2nd-cycle level). Usually awarding a master's degree.

- Third cycle: doctoral degree. No ECTS range given.

As Heinze and Knill (2008) indicated that, there are not enough well-grounded researches or analyses are found about the Bologna Process. The most important purpose of Bologna process is to develop a framework which will provide students as well as academic staff greater mobility, comparability and transparency across European Higher Education institutions (Elias, 2010). Besides, this process underlines the international aspects of higher education processes and Eu- 
ropean structures. Currently 47 countries are committed to Bologna. For the internationalization of higher education the European Credit Transfer System (ECTS) was introduced. Simultaneously, the university three-cycle degree structure reform has been brought in. Improving the quality of higher education and research, bringing new opportunities for personal growth, improving international cooperation between individuals and institutions and also mobility of staff and students are the core elements of Bologna Process. As well as ECTS, Erasmus programme is one of the outcomes of Bologna Process. As a consequence of the Erasmus programme which was established in 1997, the promotion of study abroad as a culturally and academically enriching experience, voluntarily undertaken by the students in Europe (Aittola et al, 2009).

The Erasmus Programme, together with a number of other independent programmes, was incorporated into the Socrates programme when that programme was established in 1995. However, the Socrates programme ended on 31st December 1999 (Tillekeratne and Somaratna, 2007). From the beginning of Erasmus Phase I to the end of 1989, over the four years of its existence alone the Programme supported almost 5000 inter-university cooperation agreements involving the mobility of almost 80,000 students. This shows us the program attracted the interest and participation of growing number of staff and students in universities (Absalom, 1990). Then Socrates II phase was implemented between the years 1 January 2000 and 31 December 2006. After 18 months preparatory phase of the programmes on 1st April 2004, Turkey became the 31st participating country to the Socrates II phase, Leonardo da Vinci and Youth Programmes. Turkey's budget level is about 53 million Euros per year. With this size of budget Turkey became the 7th largest country among the 31 participating countries. Turkey has 7\% of total Erasmus Programme budget which is held almost 8 billion Euros in total. In the year 2010, 129 Turkish Higher Education Institutions (HEIs) were possessing Erasmus University Charter. Table 1 shows incoming and outgoing student rates. Between the years 2004-2010 Turkish HEIs sent 30,000 students abroad and received 9,000. Besides this, HEIs sent 6,500 teaching staff and received 4,300 (Turkish National Agency, 2010). Unfortunately, as it can be seen in the table 1, there is a decreasing trend rate of outgoing students. On the contrary, there is an increasing trend rates of incoming students. This can be explained by the internationalization of Turkish higher education system through the Erasmus programme by training of students and teaching staff abroad. Besides, it provides having a contact with new cultures and new people. Some of the Turkic countries like Kazakhstan, Azerbaijan and Kyrgyzstan and also some countries like Georgia, Bosnia and Herzegovina are the signatory countries of Erasmus programme. Students could prefer Turkey for their mobility. The mobility program also the degree-program reform and the application of this program which is known as ECTS, has played a central role in the Bologna Process and Erasmus Programme (Karran, 2004).

Table1. Percentage of incoming and outgoing students 2001-2006.

\begin{tabular}{lllllll}
\hline & 2001 & 2002 & 2003 & 2004 & 2005 & 2006 \\
\hline $\begin{array}{l}\text { Students abroad (ISCED 5A-6) as \% of total } \\
\text { students }\end{array}$ & 3.7 & 2.5 & 2.4 & 2.2 & 1.9 & 1.9 \\
Foreign students as \% of total students & 1.3 & 1.2 & 0.9 & 1.0 & 1.1 & 1.3 \\
\hline
\end{tabular}

Source: EUROStat 2010 updated: 06.03.2012.

This study aims to investigate the knowledge and the impact of Erasmus program to the higher education students. To this aim answers of the following research questions are explored:

1) What are the students' opinions about Erasmus programme, European Union and membership of Turkey?

2) Is there a significant difference between the students from different genders, levels, disciplines, and knowledge of foreign language in terms of the Erasmus knowledge and perception? 
During the year 2010-2011 annual Erasmus Student Mobility (ESM) growth has been $8.5 \%$ on the previous academic year. The number of students received by the top five sending countries reveals an expected result, that larger countries in terms of population attract more ESM: these five countries are Germany, United Kingdom, France, Italy and Spain. They are the main destination for ESM. The same countries share the highest number of students participating in the Erasmus Programme except for United Kingdom. Instead of United Kingdom Poland sent the highest number of students for ESM. There was a downward trend on average student monthly grant 250 EUR $(-1.6 \%)$ throughout the years 2010-2011. 69 University Cooperation Projects were approved with a $35 \%$ success rate which was 54 Multilateral Projects; 8 Academic Networks; and 7 Accompanying Measures. Around $42 \%$ of teaching assignments were undertaken by female teachers. The average duration of student exchanges was six months. This has remained constant over the past decade. More than 45000 Erasmus students have benefited from a language course prior to their study exchange or work placement since 1999. With 1006 participants Italy was the most popular destination and it was followed by Belgium (they preferred Dutch speaking region), Portugal, Sweden and Turkey (European Commission, 2012, a and b).

This study aims at investigating the knowledge of Erasmus Programs and European Union. The study was conducted using data collected from Turkish students enrolled in the second term of the 2011-2012 academic years in a state university in Istanbul. The student questionnaire is comprised of such aspects as general information, information about and expectations from the EU, contribution of the Erasmus Programme (EP) to students' self- development, contribution of the EP to the institution's development and global benefits and expectations of the EP

\section{Method}

In this study for data collection purposes, a 15 itemed questionnaire "Erasmus Students Information and Expectations" (ESIE) questionnaire was used to obtain the students' knowledge and thought about Erasmus programme and EU. Answers are given on a 5-point Likert scale ranging from $1=$ "strongly disagree" through $5=$ "strongly agree." The study was conducted using data collected from Turkish students enrolled in the second term of the 2011-2012 academic years in a state university in Istanbul. For data collection purposes, the questionnaire was revised by subject experts and piloted on a group of 100 students. According to the feedback obtained, the necessary adaptations were done, and the questionnaire was administered. The participants were informed in the covering letter that data were being collected anonymously, and therefore, they should not write their name on the questionnaire. The respondents were invited to fill the questionnaire by their course teachers during the breaks of teaching sessions on a voluntary basis. The process of doing the questionnaire coasted each respondent about 5 minutes. Some of the questions in the questionnaire were developed by the researcher in the course of Education Policy during her $\mathrm{PhD}$ degree. These questions were used in this research as some of the research questions.

\subsection{Profile of Respondents to the Survey}

Research participants were 1546 university students $(694$ males $(\% 44,9)$ and 852 females $(\% 55,1))$ from a key university in Istanbul, Turkey. They were also asked to report their age, sex, faculty/school, knowledge of foreign language and class. Over $60 \%$ of the students in our sample were between 18 and 20 years of age. One third of respondents were in their preparatory class of study. One third was studying for Higher Education degrees of two to three years of duration. 94, 2\% of the participants knew English. Only 0, 6\% of participants didn't know any foreign languages. Participants were competent in one of the foreign languages which are English at average level (Pre-intermediate) 48, 5\% and 29, 2\% at intermediate level. Only 15, 1\% of them spoke two languages and 2, 2\% of the participants also spoke three languages. 
The participants were basically from 12 faculties and 3 schools. These faculties and schools also divided into three disciplines which were 'Medical Science', 'Science and Engineering', and 'Social Science' (Table. 2). The participants for each discipline were; 407 students were from 'Medical Science', while 306 of them were from 'Science and Engineering'. The remaining 833 students were from 'Social Science'.

Table 2. Distribution of the sample group at faculties/schools .

\begin{tabular}{|c|c|c|c|}
\hline Subject/Area & Number of participants & $\%$ of participants & Disciplines \\
\hline $\begin{array}{l}\text { Faculty of Economic-Administrative } \\
\text { Science }\end{array}$ & 103 & 6,7 & Social Sciences \\
\hline Faculty of Medicine & 101 & 6,5 & Medical Science \\
\hline Faculty of Dentistry & 104 & 6,7 & Medical Science \\
\hline Faculty of Communication & 100 & 6,5 & Social Sciences \\
\hline Faculty of Engineering & 102 & 6,6 & Eng. and Science \\
\hline Faculty of Theology & 102 & 6,6 & Social Sciences \\
\hline Faculty of Art \& Sciences & 101 & 6,5 & Eng.-Science \\
\hline Faculty of Fine Arts & 101 & 6,5 & Social Sciences \\
\hline School of Banking \& Insurance & 102 & 6,6 & Social Sciences \\
\hline Faculty of Education & 123 & 8,0 & Social Sciences \\
\hline Faculty of Pharmacy & 102 & 6,6 & Medical Science \\
\hline Faculty of Technical Education & 103 & 6,7 & Eng. and Science \\
\hline School of Physical Education-Sports & 102 & 6,6 & Social Sciences \\
\hline Faculty of Health Sciences & 100 & 6,5 & Medical Science \\
\hline Faculty of Law & 100 & 6,5 & Social Sciences \\
\hline Total & 1546 & 100,0 & \\
\hline
\end{tabular}

Source: The Author.

\subsection{Data Analysis}

The data was collected by means of the "Erasmus Students Information and Expectations" (ESIE) questionnaire developed by the researcher. To get quantitative data, students were given a list of statements (15 questions) about Erasmus Programme and European Union to indicate what the knowledge and perception of EU and Erasmus Programme are. These activities are done on a 5 point rating scale from 1 to 5 . Mean scores for each participant were calculated. Descriptive statistics were used to demonstrate the mean scores. In addition, these scores were used as the dependent variable in the statistical analysis. The independent variables were gender, age, faculty/school, academic discipline and language level. A series of T-test and One-Way ANOVA tests were utilized to identify if there was a difference with in the groups in terms of their frequency of students perception and knowledge. All statistical analysis of the quantitative results was conducted with the help of Statistical Package for Social Sciences software (SPSS), version 15.0. We have found a sta- 
tistically significant result in this example; we needed to compute a post hoc test. We selected the Tukey post hoc test. This test is designed to compare each of our conditions to every other condition and also to indicate the differences between groups. The significance was $\mathrm{p}<0,05$. This test will compare the four dimensions of Erasmus Programme.

These 15 statements were used to analyze 4 different dimensions of Erasmus Programme and European Union. One of the groups of statements was about students' information about and expectations from the EU which was questions 1,2, 3 and 6. The other group of statement was about contribution of the Erasmus Programme (EP) to students' self-development which was questions 9, 10,13,14. Another dimension was about the contribution of the EP to the institution's development. For this purpose questions 5, 7, 8 and 11 were asked. And the last point that we wanted to examine was about global benefits and expectations of the EP and the questions 4, 12, 15 were asked.

\section{Results}

The research questions of the study were related to the membership of Turkey to EU and the knowledge and perception of Erasmus Programme. On a ratings scale ranging from no importance (1) to a great deal of importance (5), the total rating is 3.14 , which is slightly above the mid-point of the scale. This indicates that generally they have a little knowledge about Erasmus programme.

Table 3 shows the frequency use of statements that were asked to the students. According to the table students feel they don't have enough knowledge of EU $(M=2.73)$. Besides, they think that Turkey wouldn't be a member of EU $(M=$ 2.89). To the statement "I have enough knowledge of foreign language (English, German, French) to study at a university in Europe" they answered between disagree and neutral $(\mathrm{M}=2,76)$. In addition, they think that they don't have enough knowledge of Erasmus Programme. They are neutral $(M=3.03)$. They are also neutral about the effects of Erasmus program to the accession of Turkey to EU and the quality of education in Turkey $(\mathrm{M}=3.21)$. Related with the question about Erasmus Programme enables the lessons in higher education more transparent and more coherent (ECTS) they feel neutral $(M=3.39)$. Besides, they are also neutral about the effect of Erasmus programme to the quality of education in Europe $(\mathrm{M}=3.37)$ and positive effect of EU higher education exchange program to the world peace and unity (3.49). On the other hand, they really want to study in Europe by means of Erasmus programme $(\mathrm{M}=3.65)$ and take lessons from a university in Europe $(\mathrm{M}=3.90)$ and they believe that it will help them to shape their career efficiently ( $\mathrm{M}$ = 3.99). Moreover, they think that the programme has more positive sides $(\mathrm{M}=3.68)$, it will provide a cultural and educational unity between European countries $(\mathrm{M}=3.52)$. And lastly, Erasmus Programme provides the collaboration between EU countries $(M=3.71)$. The total score of the frequency use was found to be 3.44 indicating that students moderately know Erasmus Programme.

73, $6 \%$ of the students reported that Erasmus period will change their career related attitudes and aspirations to a large or some extent. They think that Erasmus Programme provides very big advantage with respect to improve my career.

According to the data, the students registered in faculties and 4-year colleges constitute $70.18 \%$ of all students. Distribution of the university students by discipline was $49.32 \%$ in social sciences, $15.05 \%$ in engineering and science and $5.29 \%$ in medical sciences. As understood from the data, distribution of the ESIE respondents by discipline was found consistent with that of students registered in that university in 2011 (Marmara University, 2012). 36.1\% of study respondents do not deem themselves sufficiently informed about the EU. $30.3 \%$ are unsure about sufficiency of their knowledge. $31.9 \%$ of the respondents are undecided whether Turkey should become a member of the EU or not. While $36 \%$ of them support Turkey's accession to the EU, 32,2\% of them think that Turkey must be a member of the EU. $38,7 \%$ of the respondents do not deem themselves sufficiently informed about Erasmus Programme, $43.8 \%$ feel the opposite. $96 \%$ of the respondents speak at least one foreign language. On the other hand, $46 \%$ of them do not regard their 
foreign language level good enough to study at a European university. 24,6\% is uncertain whether their foreign language levels are sufficient or not. . As for Question 6, 47,2\% of respondents expect the Erasmus Programme to improve quality of education across Europe. In Question 9, 70\% of the respondents are highly enthusiastic about taking courses related with their own subject at a foreign university, although they do not regard their foreign language levels sufficient enough. Also they mentioned that participating in that program would help them a lot in finding a job later. As for Question 11, the respondents stated that ECTS helps the EU education be more transparent and harmonious within the framework of the Bologna process (50,2 \%). 29,6\% of the respondents remained indecisive about this matter. In relation Question 12, although 23,7\% of the respondents are undecided about this issue, 58\% find the Erasmus Programme functional for bringing international collaboration in education and common culture. For Question 13, 60,2\% of the respondents are willing to study in a European university through Erasmus Programme, whereas $22.4 \%$ is undecided. In Question 14, 73.6\% of the respondents expects that the Erasmus Programme will have a big impact on their career and facilitating the job finding process than others' that have not participated in that programme. For Question 15, 64,2\% of them think Erasmus is increasing collaboration among higher education institutions across Europe and it allows universities to share their educational experiences.

Table 3. Participants opinions about the statements.

\begin{tabular}{|c|c|c|}
\hline Statement & Mean & $\sigma$ \\
\hline 1) I have enough knowledge about EU & 2,73 & 1,046 \\
\hline 2)I have a positive look for accession of Turkey to EU & 2,89 & 1,237 \\
\hline 3)I have previous knowledge about Erasmus programme & 3,09 & 1,213 \\
\hline $\begin{array}{l}\text { 4) I believe that EU higher education exchange programs lean } \\
\text { to positive view of students to the world peace, unity }\end{array}$ & 3,49 & 1,177 \\
\hline $\begin{array}{l}\text { 5)I think the success of Erasmus Program in Turkey will } \\
\text { affect the accession of Turkey to EU }\end{array}$ & 3,21 & 1,212 \\
\hline $\begin{array}{l}\text { 6) Erasmus education programme increases the quality of } \\
\text { education in Europe }\end{array}$ & 3,37 & 1,034 \\
\hline $\begin{array}{l}\text { 7)I believe that Erasmus Programme increases the quality of } \\
\text { education at universities in Turkey }\end{array}$ & 3,21 & 1,322 \\
\hline $\begin{array}{l}\text { 8)This programme has more positive sides than its negative } \\
\text { sides }\end{array}$ & 3,68 & 1,015 \\
\hline $\begin{array}{l}\text { 9)I hope to take lessons from a university in Europe and } \\
\text { replace them at my university }\end{array}$ & 3,90 & 1,168 \\
\hline $\begin{array}{l}\text { 10) I have enough knowledge of foreign language( English, } \\
\text { German, French) to study at a university in Europe }\end{array}$ & 2,76 & 1,290 \\
\hline $\begin{array}{l}\text { 11) Erasmus Programme enables the lessons in higher edu- } \\
\text { cation more transparent and more coherent to EU standards } \\
\text { (ECTS) }\end{array}$ & 3,39 & 1,086 \\
\hline $\begin{array}{l}\text { 12) Erasmus Programme functional for bringing interna- } \\
\text { tional collaboration in education and common culture be- } \\
\text { tween European countries }\end{array}$ & 3,52 & 1,118 \\
\hline $\begin{array}{l}\text { 13) I want to study at a university in Europe by means of } \\
\text { Erasmus Programme }\end{array}$ & 3,65 & 1,225 \\
\hline $\begin{array}{l}\text { 14)Erasmus Programme provides very big advantage with } \\
\text { respect to improve my career related attitudes and aspirations } \\
\text { to a large or some extent }\end{array}$ & 3,99 & 1,483 \\
\hline $\begin{array}{l}\text { 15) Erasmus Programme provides the collaboration between } \\
\text { EU countries to share their experiences in higher education }\end{array}$ & 3,71 & 0,970 \\
\hline
\end{tabular}

\section{a. Relationship between ages and aspects of ESIE questionnaire.}


A one-way between subjects ANOVA was conducted to compare the ages of students with their knowledge about EU, student dimension of Erasmus programme, institutional dimension of Erasmus Programme and Global profits of Erasmus programme. The participants were between the ages of 18 to 27. In the aspects of students' knowledge about and expectations from the EU, Erasmus students' self-development, institutional contribution and global benefits, a significant difference was found by respondents' ages. There was a statistically significant difference between groups as determined by one-way ANOVA $(\mathrm{F}(9,1536)=2.800, \mathrm{p}=.003)$. Our significance value is .003 . We can say that there is a significant difference between the ages and the European Union knowledge of the students (Table 4).

Table 4. One-way analysis of variance of ages in ESIE by four erasmus dimensions.

\begin{tabular}{|c|c|c|c|c|c|}
\hline & Source & Sum of Squares & df & $\begin{array}{c}\text { Mean } \\
\text { Square }\end{array}$ & $\mathrm{F}$ \\
\hline Knowledge & Between Groups & 11,711 & 9 & 1,301 & $2,800^{*}$ \\
\hline \multirow[t]{2}{*}{ about EU } & Within Groups & 713,897 & 1536 & ,465 & \\
\hline & Total & 725,608 & 1545 & & \\
\hline Students' & Between Groups & 34,668 & 9 & 3,852 & $6,882 * *$ \\
\hline \multirow[t]{2}{*}{ Self- development } & Within Groups & 859,690 & 1536 &, 560 & \\
\hline & Total & 894,358 & 1545 & & \\
\hline Institution's & Between Groups & & 9 & 2,621 & $5,179 * *$ \\
\hline \multirow[t]{2}{*}{ Development } & Within Groups & & 1536 &, 506 & \\
\hline & Total & & 1545 & & \\
\hline Global Benefits & Between Groups & & 9 & 3,024 & $4,448 * *$ \\
\hline \multirow[t]{2}{*}{ of EP } & Within Groups & & 1536 &, 680 & \\
\hline & Total & & 1545 & & \\
\hline
\end{tabular}

$* \mathrm{p}<0,05 ; * \mathrm{p}<0,01$

Another one-way ANOVA was used to test for preference differences among the ages and students aspects from Erasmus programme. The expectations of and aspects of the students from Erasmus programme differed significantly across the ages, $\mathrm{F}(9,1536)=6.882, \mathrm{p}=.000$. The anova results of university dimension and global dimension were significant, $\mathrm{F}(9,1536)=5.179, \mathrm{p}=.000$. Our $\mathrm{F}$ value for global dimension is 4.448 and our significance value is .000 . According to these results there is a significant relationship between the ages of respondents and the dimensions of EP.

The relationship between respondents' age and ESIE questionnaire was found significantly different for each of the aspects. As respondents' ages increase, the information levels they have about the EU increases, their views about Turkey's accession to the EU becomes more positive, and they become more conscious about the contributions of the Erasmus Programme to their personal development as well as the global benefits of Erasmus and contributions of it to their home institutions.

\section{b. Relationship between gender and aspects of ESIE questionnaire.}

Independent T-Test was conducted on the dimensions of Erasmus programme among gender. Either the EU knowledge of the students, $\mathrm{t}(\mathrm{df})=-1386,622, \mathrm{p}=, 000$, or interaction of university dimension of Erasmus programme $\mathrm{t}(\mathrm{df})=$ $1438,026, \mathrm{p}=0,49$, had a statistically significant impact on gender (Table 5). However, there were no statistically significant differences between the student dimension of EP and gender $(\mathrm{p}=.806)$. A small probability is obtained when the statistic is sufficiently large, indicating that the two means significantly differ from each other $\mathrm{t}(\mathrm{df})=-1438,026, \mathrm{p}=, 049$ about contribution of the EP to the institution's development also for global benefits dimension of EP $t(d f)=1425,400, p$ $=0,05$. 
Table 5. Change in erasmus dimensions for male and female respondents.

\begin{tabular}{|c|c|c|c|c|c|c|}
\hline \multirow[b]{3}{*}{ Dimension } & \multicolumn{4}{|c|}{ Gender } & \multirow[b]{3}{*}{$\mathrm{t}$} & \multirow[b]{3}{*}{$\mathrm{df}$} \\
\hline & \multicolumn{2}{|c|}{ Male } & \multicolumn{2}{|c|}{ Female } & & \\
\hline & Mean & $\mathrm{SD}$ & Mean & SD & & \\
\hline $\begin{array}{l}\text { Knowledge } \\
\text { about EU }\end{array}$ & 3,0666 & ,73363 & 2,98 & ,64125 & $-2,40$ & $1386,622 * *$ \\
\hline $\begin{array}{l}\text { Students' } \\
\text { self-developme } \\
\text { nt }\end{array}$ & 3,5317 & ,76746 & 3,6012 &, 75441 & 1,789 & $1471,076 * * *$ \\
\hline $\begin{array}{l}\text { Institution's } \\
\text { Development }\end{array}$ & 3,3177 &, 74482 & 3,4129 & ,69672 & 1,785 & $1438,026^{* *}$ \\
\hline Development & 3,4693 &, 86546 & 3,6604 & ,79558 & 4,478 & $1425,400 * *$ \\
\hline
\end{tabular}

Note: 694 men +852 women distributed equally.

$* * \mathrm{p}<0,05 ; * * * \mathrm{p}>0,05$

As seen in Table 5, there are statistically significant differences between male and female respondents in three of the four aspects. It means that the respondents' views about the EU, benefits of the Erasmus program for the university and global benefits of it varies significantly between two genders. However, there is not any significant difference between female and male respondents by means of students' self-development dimension. Therefore, it can be inferred that, regardless of their gender, the respondents' evaluations on all of the four aspects regarding their Erasmus experiences are not different from each other. For information about and expectations from the EU dimension male respondents have slightly more knowledge than female respondents. Also the awareness of female students about contribution of the EP to the institution's development and global benefits and expectations of the EP was higher than male. Therefore, it can be inferred that, regardless of their gender, the respondents' evaluations on three of the four aspects regarding their Erasmus experiences are different from each other except for the evaluations about students' self-development dimension.

\section{c. Relationship between school year and aspects of ESIE questionnaire.}

Students attending preparation year, 1st year, 2nd year, 3rd year 4th year and 5th year (Master degree for faculty of education students) participated in this study. One-way Anova analysis was conducted to find out if there is a significant relationship between the aspects of the ESIE questionnaire by year independent variable (prep, 1, 2, 3, 4, 5) with their knowledge about EU, student dimension of Erasmus programme, institutional dimension of Erasmus Programme and Global profits of Erasmus programme (Table 6). There was a statistically significant difference between groups as determined by one-way ANOVA $[\mathrm{F}(5,1540)=2.800, \mathrm{p}=.000]$. There was a significant effect of school years on students's self-development about EP at the $\mathrm{p}<.05$ level. $[\mathrm{F}(5,1540)=5,099, \mathrm{p}=, 000]$. Also, there was a significant effect of amount of school years on institution's development at the $\mathrm{p}<.05$ level for the three conditions $[\mathrm{F}(5,1540)=4,292$, $\mathrm{p}$ $=, 001]$.

It is seen in the table that respondents' views are significantly different by their year only in the aspect about the contribution of the Erasmus Programme to the institutional development. As respondents are closer to late years in university, they are of the opinion that Erasmus makes even more contribution to their institution in addition to themselves. The higher the year of the students is, the lesser the significance level of the difference between student aspect, EU aspect and global benefit aspect in overall EP perception. As it can be seen from the results there is a positive relationship between school years and students' knowledge and aspects about Erasmus programme. 
Table 6. One-way analysis of variance of school years in ESIE by four erasmus dimensions.

\begin{tabular}{|c|c|c|c|c|c|}
\hline & Source & Sum of Squares & df & $\begin{array}{l}\text { Mean } \\
\text { Square }\end{array}$ & $\mathrm{F}$ \\
\hline \multirow{3}{*}{$\begin{array}{l}\text { Knowledge } \\
\text { about EU }\end{array}$} & Between Groups & 12,935 & 5 & 2,587 & \multirow[t]{3}{*}{$5,590 * * * *$} \\
\hline & Within Groups & 712,673 & 1540 & ,463 & \\
\hline & Total & 725,608 & 1545 & & \\
\hline Students' & Between Groups & 25,497 & 5 & 5,099 & \multirow[t]{3}{*}{$9,038 * * * *$} \\
\hline \multirow[t]{2}{*}{ Self- development } & Within Groups & 868,861 & 1540 &, 564 & \\
\hline & Total & 894,358 & 1545 & & \\
\hline Institution's & Between Groups & 11,007 & 5 & 2,201 & \multirow[t]{3}{*}{$4,292 * *$} \\
\hline \multirow[t]{2}{*}{ Development } & Within Groups & 789,987 & 1540 &, 513 & \\
\hline & Total & 800,995 & 1545 & & \\
\hline \multirow{3}{*}{$\begin{array}{l}\text { Global Benefits } \\
\text { of EP }\end{array}$} & Between Groups & 15,934 & 5 & 3,187 & \multirow[t]{3}{*}{$4,649 * * * *$} \\
\hline & Within Groups & 1055,740 & 1540 & ,686 & \\
\hline & Total & 1071,674 & 1545 & & \\
\hline
\end{tabular}

$* * \mathrm{p}<0,05 ; * * * * \mathrm{p}=0,00$

\section{d. Relationship between foreign language level and aspects of ESIE questionnaire.}

The relationship between ESIE questionnaire aspects depending on students' foreign language level as an independent variable was explained by the application of one-way Anova analysis. As seen in Table 7, respondents' views are found to vary significantly by four of the aspects $[\mathrm{F}(4,1541)=10,349, \mathrm{p}=, 001]$ about knowledge about EU. There was a significant effect of foreign language knowledge on dimensions of EP at the $\mathrm{p}<.05$ level for the three conditions $[\mathrm{F}(4,1541)$ $=13,910, \mathrm{p}=, 000]$. There was a statistically significant difference between groups as determined by one-way ANOVA $[\mathrm{F}(4,1541)=7,799 \mathrm{p}=.000]$ about institution's development dimension of EP. The higher the respondents' language level is, the higher their perception related with the Erasmus Programme is. A significant difference was found between 4 aspects of the ESIE questionnaire and foreign language level. It is possible to interpret it in two different ways. Those

Table 7. One-way analysis of variance of foreign language level in ESIE by four erasmus dimensions.

\begin{tabular}{llllll}
\hline & & Sum of & & Mean \\
& Source & Squares & df & Square & F \\
\hline Knowledge & Between Groups & 18,981 & 4 & 4,745 & 10,349 \\
about EU & Within Groups & 706,627 & 1541 &, 459 & \\
Students' & Total & 725,608 & 1545 & & \\
Self- development & Between Groups & 31,168 & 4 & 7,792 & 13,910 \\
& Within Groups & 863,190 & 1541 &, 560 & \\
Institution's & Total & 894,358 & 1545 & & \\
Development & Between Groups & 15,894 & 4 & 3,974 & \\
& Within Groups & 785,101 & 1541 &, 509 & \\
Global Benefits & Total & 800,995 & 1545 & & \\
of EP & Wetween Groups & 8,292 & 4 & 2,004 \\
& Total & 1063,382 & 1541 &, 690 & \\
\hline
\end{tabular}

students with a high language level show more interest in the Erasmus Programme, are better informed about the EU and 
become more aware of the contribution that program will offer to their home institution. They are also conscious about global benefits of it.

As can be understood easily, institutions should support their students in order to improve their foreign language levels eventually to increase their interest and participation in Erasmus. However, it was seen that respondents' speaking a second or third language does not make a difference in terms of awareness about Erasmus. Taken together, these results suggest that high levels of sugar really do have an effect on memory for words. Specifically, our results suggest that when humans consume high levels of sugar, they remember more words. However, it should be noted that sugar level must be high in order to see an effect. Medium sugar levels do not appear to significantly increase word memory.

\section{e. Relationship between disciplines and aspects of ESIE questionnaire.}

As seen in Table 8, there is not a statistically significant difference between three disciplines which are social science, medical science and Science and Engineering with in any of the four aspects. It means that the respondents' views about the EU, benefits of the Erasmus programme both for students and the university and global benefits of it do not vary significantly between disciplines. Therefore, it can be inferred that, regardless of their gender, the respondents' evaluations on all of the four aspects regarding their Erasmus experiences are not different from each other. Likewise, no significant difference was found in these four aspects by discipline studied by respondents.

Table 8. One-way analysis of disciplines in ESIE by four erasmus dimensions.

\begin{tabular}{|c|c|c|c|c|c|}
\hline & Source & Sum of Squares & df & $\begin{array}{l}\text { Mean } \\
\text { Square }\end{array}$ & $\mathrm{F}$ \\
\hline Knowledge & Between Groups &, 723 & 2 &, 362 &, 770 \\
\hline \multirow[t]{2}{*}{ about EU } & Within Groups & 724,885 & 1543 &, 470 & \\
\hline & Total & 725,608 & 1545 & & \\
\hline Students' & Between Groups & 1,661 & 2 &, 830 & 1,435 \\
\hline \multirow[t]{2}{*}{ Self- development } & Within Groups & 892,697 & 1543 &, 579 & \\
\hline & Total & 894,358 & 1545 & & \\
\hline Institution's & Between Groups & 1,262 & 2 & 631 & 1,217 \\
\hline \multirow[t]{2}{*}{ Development } & Within Groups & 799,733 & 1543 &, 518 & \\
\hline & Total & 800,995 & 1545 & & \\
\hline \multirow{3}{*}{$\begin{array}{l}\text { Global Benefits } \\
\text { of EP }\end{array}$} & Between Groups & 1,943 & 2 & 971 & 1,401 \\
\hline & Within Groups & 1069,731 & 1543 & 693 & \\
\hline & Total & 1071,674 & 1545 & & \\
\hline
\end{tabular}

\section{Conclusion and Recommendations}

European Union Education and Youth Programmes reached its third period, 2007-2013 periods, by renewing itself since the first day of such programmes and utilizing the results obtained in the past in the right direction. The reason is that accurate and effective implementation of the Erasmus Programme by higher education institutions and students' knowing it accurately is of high importance for the implementations and improvement of the overall program. Present study is also important for obtaining students' views about effectiveness of the Erasmus Student Learning Mobility in Turkey and the European Union. This article analyses the Erasmus program from the point of view of Turkish university students. 15 itemed questionnaires were grouped into 4 sub-categories; information about and expectations from the EU, contribution of the Erasmus Programme (EP) to students' self-development, contribution of the EP to the institution's development and global benefits and expectations of the EP. The problem statements are; what the university students think about membership of Turkey to EU. Do they think they have knowledge of EP, individual benefits of EP and also 
institutional benefits of EP?

The results showed that students feel they don't have enough knowledge of EU. Besides, they think that Turkey wouldn't be a member of EU. Since Erasmus had a considerable impact on the higher education institutions, certain issues (credit transfer-ECTS, differences between national structures and degree recognition) became more important elements on the higher education policy agendas of responsible national ministries (Huisman et al., 2005). In our study the respondents stated that ECTS helps the EU education be more transparent and harmonious within the framework of the Bologna process. As well as the research of Aittola et al. (2009), our research also showed that the interviewees felt that the Bologna Process enables students' willing to study another university in Eurpoe by means of EP which provides harmonization and comparability of higher education in Europe. Erasmus Programme functional for bringing international collaboration in education and common culture On the other hand, the study has such aspects as the EU, contributions of the Erasmus Programme to students and their awareness, institutional benefits of the EP and global benefits of the Erasmus Programme. Other studies about Erasmus Student Learning Mobility also demonstrate that the program provides individuals with opportunities like foreign language learning, studying abroad, career development, and respecting different cultures (Sirok et al, 2007). According to the study findings, students with high foreign language level have higher awareness about the program and are more interested in taking part in the program. It reveals that the students are sufficient in a foreign language, the more they are informed about Erasmus mobility and the more they are willing to take part on the program. In general, it has contributions to the advantages such as being international, increasing visibility of higher education institutions, developing collaboration among institutions on the same platform and arising corresponding higher education policies (Maiworm, 2001). Bologna process is one of the institutional- level rationales of internationalization and also it is a top-down process. By this way it provides the student and staff development (Knight, 2004).Seen as an instrument of being international, the Erasmus Programme provides opportunities for not only the improvement of those participating for cooperation or mobility between institutions, but also who have not realized mobility yet. So, it can be suggested that Erasmus Programme is a process which affects not only individuals participating in mobility but also the institution as a whole. This study investigates 1546 university students influence of the programme on institutional development of higher education institutions and students not involved in the mobility, its contribution to global improvement and institutions. It is suggested to consider present study data within the framework of an important limitation. Study respondents include students studying in a reputable Turkish university during 2011-2012 academic year. Although findings of this study reflect views of a large group of students, it cannot be generalized to all students. Therefore, it should be taken into consideration that findings here could have limited external validity.

\section{References}

Absalom, R. (1990). Practical Rather than Declamatory Cooperation': Erasmus in 1990, an appraisal. European Journal of Education, 25(1), 39-54.

Aittola, H., Kiviniemi, U., Honkimaki, S., Muhonen, R., Huusko, M., \& Ursin, J. (2009). The Bologna Process and Internationalization-Consequences for Italian Academic Life. Higher Education in Europe, 34(3-4), 303-312.

Brookes, M., \& Huisman, J. (2009). The Eagle and the Circle of Gold Stars: Does the Bologna Process Affect US Higher Education? Higher Education in Europe, 34(1), 3-23.

Elias, M. (2010). Impact of the Bologna Process on Spanish Students' Expectations. International Journal of Iberian Studies, 23(1), 53-62.

Engelberg, E., \& Limbach-Reich, A. (2009). After the Bologna Reform: Employability of Bachelors in Social and Educational Work in Luxembourg. Social Work Education, 31(7), 807-818.

Eurostat. (2010), Mobility Statistics 2001-2006. http://appsso.eurostat.ec.europa.eu/nui/show.do?dataset=educ_bo_mo_el8o\&lang=en and http://appsso.eurostat.ec.europa.eu/nui/show.do?dataset=educ_bo_mo_el8i\&lang=en. Accessed 08 May 2012. 
European Commission. (2007). Focus on the Structure of Higher Education in Europe: National Trends in the Bologna Process, European Commission Directorate-General for Education and Culture. http://www.nefmi.gov.hu/letolt/felsoo/eurydice_086en_070601.pdf Accessed 18 April 2012.

European Commission. (2012a). Lifelong Learning Programme, The Erasmus Programme 2010-2011 A Statistical Overview. http://ec.europa.eu/education/erasmus/doc/stat/1011/report.pdf Accessed 20 January 2013.

European Commission. (2012b). Erasmus Facts-Figures and Trends. http://ec.europa.eu/education/pub/pdf/higher/erasmus1011_en.pdf Accessed 20 January 2013.

European Commission. (2013). Education and Training-The Erasmus Programme- studying in Europe and More. http://ec.europa.eu/education/lifelong-learning-programme/erasmus_en.htm. Accessed 20 January 2013.

Furuzan, V. G. (2012). Adaptation to the Bologna Process: The Case of Turkey. Excellence in Higher Education. 3, $104-110$.

Garben, S. (2010). The Bologna Process: From a European Law Perspective. European Law Journal, 16(2), 186-210.

Heinze, T., \& Knill, C. (2008). Analysing the Differential Impact of the Bologna Process: Theoretical Considerations on National Conditions for International Policy Convergence. Higher Education, 56, 493-510.

Huisman, J., Luijten-Lub, A., \& van der Wende, M., (2005). Explaining Domestic Responses to European Policies: The Impact of the Erasmus Programme on National Higher Education Policies. International Perspectives on Higher Education Research, 3, 5-27.

Karran, T., (2004). Achieving Bologna Convergence: Is ECTS failing to make the grade? Higher Education in Europe, 29(3), 411-421.

Kehm, B. M., (2010). European Education The Influence of Bologna Process. Change Magazine. http://www.changemag.org/Archives/Back\%20Issues/May-June\%202010/quality-european-full.html Accessed 10 December 2012. Accessed 10 December 2012.

Knight, J., (2004). Internationalization Remodeled: Definition, Approaches, and Rationales. Journal of Studies in International Education, $8(1), 5-31$.

Marmara University. (2012). Marmara University Statistics. http://www.marmara.edu.tr/universite/genel/istatistikler/. Accessed 10 December 2012

Maiworm, M. F., (2001). ERASMUS: Continuity and Change in the 1990s. European Journal of Education, 36(4), $459-472$.

Mercer, J. (2010). Experiencing ERASMUS: Reflections on integrating Polish psychology students onto a ye ar of a degree in the UK. Psychology Teaching Review, 17(1), 13-22.

Papatsiba, V. (2005). Political and Individual Rationales of Student Mobility: a case-study of ERASMUS and a French regional scheme for studies abroad. European Journal of Education, 40(2), 173-188.

Sihvonen, J. R., Tissari, V., Ots, A., \& Uusiautti, S. (2011). Teacher Education Curricula after the Bologna Process - a Comparative Analysis of Written Curricula in Finland and Estonia. Scandinavian Journal of Educational Research. 56(3), 261-275.

Sirok, K., Dermol, V., Rajh, A. J., Marjetic, D., \& Sirca, N. T., (2007). Socrates and Leonardo da Vinci in Slovenia: Impact of Socrates II and Leonardo da Vinci II Programmes in Slovenia, 2000-2006", Koper, University of pp.58-60.

Teicher, U. (1996). Student Mobility in the Framework of ERASMUS: Findings of an Evaluation Study. European Journal of Education, 31(2), 153-179.

Teicher, U. (2001) Changes of ERASMUS under the Umbrella of SOCRATES. Journal of Studies in International Education, 5, $201-227$.

Tillekeratne, K., \& Somaratna, K. T. (2007). Development of a Credit Accumulation and Transfer Scheme (CATS) for the Sri Lankan University Sector. National Education Commission Sri Lanka. Study Series No:3 (2007/2008). http://www.nec.gov.lk/web/images/pdf/research/higher/Development_of_a_Credit_Accumulation_and_Transfer_Scheme.pdf. Accessed 20 January 2013.

Turkish National Agency. (2010). Study in Turkey for Erasmus. The Center for EU Education and Youth Programmes. 4th Edition. Ankara. 